\title{
Quantification of Frailty Syndrome in ICU Patients with Clinical Frailty Scale
} \author{
Keskou $^{4}$, Christina Mandila ${ }^{5}$ \\ ${ }^{1}$ ICU Follow-up Care Lab, Department of Nursing, University of West Attica, Athens, Greece \\ ${ }^{2}$ Registered Nurse, Athens, Greece \\ ${ }^{3}$ Errikos Ntinan Hospital Center, Athens, Greece \\ ${ }^{4}$ Department of Medicine, National and Kapodistrian University of Athens, Greece \\ ${ }^{5}$ Intensive Care Unit, GNA G. Gennimatas, Athens, Greece
}

Dimitrios Papageorgiou ${ }^{1}$, Konstantina Kosenai ${ }^{2}$, Eleni Gika ${ }^{2}$, Dimitrios Alefragkis ${ }^{3,4}$, Despoina

Corresponding author: Dimitrios Papageorgiou, ICU Follow-up Care Lab, Department of Nursing, University of West Attica, Athens, Greece; E-mail: dpapa@teiath.gr

Received: 24 Jan 2020 Accepted: 15 Apr $2020 \diamond$ Published: 31 Dec 2020

Citation: Papageorgiou D, Kosenai K, Gika E, Alefragkis D, Keskou D, Mandila C. Quantification of frailty syndrome in ICU patients with clinical frailty scale. Folia Med (Plovdiv) 2020;62(4):655-61. doi: 10.3897/folmed.62.e50433.

\begin{abstract}
Quantification of frailty is useful both for understanding the nature of the syndrome and for designing an ICU care plan for patients that suffer from it. Knowing the needs and deficits of each patient individually, it is possible to create a care plan suitable to cover all the patients' needs. Tools used to date to quantify frailty syndrome are the Fried phenotype, Frailty index, Edmonton Frailty Scale, and Clinical Frailty Scale. The Clinical Frailty Scale is one of the most user-friendly scales with particular predictive value. By recording and analyzing the information collected and ranking ICU patients at nine points on the scale, it is possible to draw valid predictive conclusions about the mortality or institutionalization needs that are present within the next five years.
\end{abstract}

\section{Keywords}

critically ill patients, frailty syndrome, ICU

\section{INTRODUCTION}

In recent years, a systematic effort has been made to measure and determine the biological age of an individual. It is speculated that aging process leads to the onset of the frailty syndrome in association with the mechanism by which the inflammation process occurs during the life of the individual. ${ }^{1}$ Systematic literature surveys indicate that people who are at a state of frailty or pre-frailty have high levels of interleukin, but also elevated levels of white blood cells and fibrinogen. ${ }^{2}$ Genetic polymorphism in the pre-inflammatory and anti-inflammatory stages is a mechanism which can explain some individual variations in the rate of aging and can explain the poor strength of the age thus providing a solution to the result. ${ }^{1}$
Quantification of frailty is therefore useful both for understanding the nature of the syndrome and for diagnosing and planning care for people suffering from it. Additional information is received which will contribute to the assessment of the results and the individual risks. These purposes create the necessity to use different indicators of frailty. When the purpose is just rough approach to people at risk, the classification of whether frailty is present or not is necessary. However, if the degree of risk is fluctuating, it would be beneficial to carry out measurements to determine the degree of frailty. Measurement methods should therefore be applied and assessed according to the objectives of each use. ${ }^{3}$

The tools that have been used up to date for quantification of frailty are the Fried phenotype, Frailty index (FI), Ed- 
monton Frailty Scale (EFS) and Clinical Frailty Scale (CFS). With Fried's phenotype, if one has three characteristics or more that define frailty, he is called weak, if he has 1 or 2 characteristics he is placed in the stage of early frailty and if he has none of them - ill. The frailty index consists of seventy questions. It is mainly used in surgical patients and is capable of detecting patient deficits, which can negatively affect their outcome within the ICU. ${ }^{1}$ Edmonton Frailty Scale, which is classified as $0-17$, is valid and can be easily used even by non-geriatric individuals, but it has many limitations to the interview process as patients are not always able to answer questions and also many times the answers cannot be evaluated for their validity and the actual problems of the patients are separated from the problems that are probably related to other social, cognitive or problems at their disposal (Table 1). ${ }^{4-6}$ activities, the symptoms they presented with significantly reduced their daily activities and at the end of the day they often experienced fatigue. Moderately weak people were classified as the fifth category members. These people had more pronounced diminished activity and were weakening even in simple day-to-day activities such as moving, heavy homework and shopping. In the seventh category, severely frail individuals were classified, those who were completely dependent on others but did not present a serious risk of death. In the eighth category, people with very severe weakness were included, people who were absolutely dependent on others and reached the limits of death, as they rarely recovered from a mild illness. Finally, in the last category, which is the ninth in the series, were the final stage patients that were at the limit of death, with a life expectancy less than six months. ${ }^{6,7}$

Table 1. Comparison between the three certified Frailty scales

\begin{tabular}{|c|c|c|c|c|}
\hline & $\begin{array}{l}\text { Description } \\
\text { and categories }\end{array}$ & $\begin{array}{l}\text { Results (risk ratio } \\
\text { and } 95 \% \text { confidence } \\
\text { interval for death and } \\
\text { institutionalization) }\end{array}$ & Advantages & Disadvantages \\
\hline \multirow{3}{*}{$\begin{array}{l}\text { Fried Phe- } \\
\text { notype }\end{array}$} & - Frailty $=\geq 3$ characteristics & \multirow{3}{*}{$\begin{array}{l}1.17(1.13-1.20) \\
1.27(1.19-1.35)\end{array}$} & $\begin{array}{l}\text { - It intends to estimate } \\
4 \text { out of } 5 \text { items }\end{array}$ & - Incorrect ranking \\
\hline & $\begin{array}{l}\text { - Pre-stage of frailty }=\geq 2 \\
\text { characteristics }\end{array}$ & & $\begin{array}{l}\text { - Valid for predicting } \\
\text { health outcomes }\end{array}$ & $\begin{array}{l}\text { - Lack of consensus in } \\
\text { the nature and number of } \\
\text { objects. }\end{array}$ \\
\hline & $\begin{array}{l}\text { - Non Frail=no character- } \\
\text { istics }\end{array}$ & & $\begin{array}{l}\text { - Correlation with these } \\
\text { physiological indicators } \\
\text { in poor health outcomes } \\
\text { including hemoglobin and } \\
\text { proinflammatory markers }\end{array}$ & $\begin{array}{l}\text { - It does not categorize the } \\
\text { degree of frailty }\end{array}$ \\
\hline $\begin{array}{l}\text { Clinical } \\
\text { Frailty Scale }\end{array}$ & $\begin{array}{l}\text { Physical arrangement (see } \\
\text { Table 2) and according to } \\
\text { the overall clinical assess- } \\
\text { ment. }\end{array}$ & $\begin{array}{l}1.30(1.27-1.33) \\
1.46(1.39-1.53)\end{array}$ & Clinically feasible & $\begin{array}{l}\text { It requires additional data } \\
\text { on the feasibility and valid- } \\
\text { ity in the clinical environ- } \\
\text { ment }\end{array}$ \\
\hline Frailty Index & $\begin{array}{l}\text { Present health problems/ } \\
\text { potential health problems }\end{array}$ & $\begin{array}{l}1.26(1.24-1.29) \\
1.56(1.48-1.65)\end{array}$ & $\begin{array}{l}\text { Can be used in all popula- } \\
\text { tion and diseases. }\end{array}$ & $\begin{array}{l}\text { Difficulty in using it in the } \\
\text { clinical environment. }\end{array}$ \\
\hline
\end{tabular}

In 1991, Rockwood and his team launched an investigation conducted in three different stages that concerned the study and formulation of Clinical Frailty Scale (CFS). The scale was as follows: the studied subjects belonged to the age group over 65 years of age. Based on their characteristics and general health status, these individuals were categorized into 9 categories (Table 2). The first category included people who had a very good physical condition, with energy and rich physical activity. To the second category belonged the first-class individuals with less good physical condition. The third category of CFS included those who were properly managed with the health problems they suffer from but did not have physical activity. The fourth category of the scale was for people who were vulnerable. While they did not rely on other people in their day-to-day

\section{USE OF CFS IN SEVERELY ILL PATIENTS}

If a tool is to be used when inserting the patient in the ICU, it should be easy to understand and the fill time is small. In addition, the information requested should be answered by friends and family, as the patient is often unable to respond due to his or her condition. The CFS can be read on the edge of the bed and is easier to understand and use than other tools. It receives subjective information and the range of this information can create a picture of patient morbidity. This flexibility is a dominant asset and has been evaluated in other environments as well. ${ }^{1,7}$

CFS is used by hospital researchers even by telephone, 
Table 2. Clinical Frailty Scale components

\begin{tabular}{|c|c|c|}
\hline Score & Degree of frailty & Description \\
\hline 1 & Very Fit & $\begin{array}{l}\text { People who are active and energetic. These people commonly exercise regularly and are in } \\
\text { the fittest for their age. }\end{array}$ \\
\hline 2 & Good physical condition & $\begin{array}{l}\text { People who have no active disease but are less fit that category } 1 \text {. They exercise often or } \\
\text { occasionally. }\end{array}$ \\
\hline 3 & Proper health management & People who manage their health issues properly, but do not walk systematically. \\
\hline 4 & Vulnerable & $\begin{array}{l}\text { While not relying on others in everyday life, often symptoms limit activity. These people } \\
\text { show inconvenience and fatigue during the day. }\end{array}$ \\
\hline 5 & Mildly frail & $\begin{array}{l}\text { These people have more visible activity and need help in their day-to-day activities (financ- } \\
\text { es, transportation, heavy housework, care). Typically, a mildly frail person is progressively } \\
\text { unable to walk, prepare food, do shopping and housekeeping. }\end{array}$ \\
\hline 6 & Moderately frail & $\begin{array}{l}\text { People need help with all activities that take place either inside or outside the home. Inside } \\
\text { they usually have trouble with stairs and need help in bathing and little help in dressing. }\end{array}$ \\
\hline 7 & Severe frailty & $\begin{array}{l}\text { Complete dependence on personal care (mental, physical). However, they are stagnant and } \\
\text { there is no serious risk of death. }\end{array}$ \\
\hline 8 & Very severe frailty & $\begin{array}{l}\text { Absolutely dependent on others, reaching the limits of death. They cannot recover from } \\
\text { mild illness. }\end{array}$ \\
\hline 9 & Terminally ill patients & $\begin{array}{l}\text { At the limits of death. This category refers to people with less than } 6 \text { months on mechanical } \\
\text { support who are not otherwise visibly frail. }\end{array}$ \\
\hline
\end{tabular}

since the information collected is very useful in the medical historical process. Recognizing that frailty is not a static condition, evaluating the diagnosed weak patient and quantifying the development of frailty during hospitalization in the ICU, a clear picture of the outcome of its hospitalization can also be made. In addition to assessing the weakness of the patient's entry into the ICU, CFS can, through friends and family, see physical and mental functions in the recent past and thus provide a health assessment before illness. ${ }^{8,9}$

\section{ADVANTAGES OF CFS}

The advantages of CFS concern both the practice of use and the significance of the information it collects. Practically, it is easy for the questions that need to be answered to be collected from both the relative and the patient's environment if he/she is unable to answer. In some cases, nurses abroad collect information even by phone. The data gathered on the basis of the questions is sufficient to complete the patient's history. ${ }^{1}$ By recording and analyzing the information gathered and ranking them on the nine points of the scale, it is possible to draw valid predictive conclusions about the mortality rates or the need for institutionalization that exist within the next five years. ${ }^{7}$ Recognizing that frailty is a non-static situation and creating an image of the progression of the syndrome during hospitalization in an ICU, it is concluded that its predictive value is particularly important. In addition, patient assessment based on this scale gives an overview of its health status in the recent past, a key to designing the care plan. ${ }^{3,10}$ It is very useful for the ICU medical staff to be able to provide family information even when it comes to the end of life, with a personalized prognosis. ${ }^{1,11}$

\section{OBSTACLES TO THE USE OF THE CFS}

Researchers who have been working on quantifying frailty syndrome and using CFS in recent years recognize the usefulness of the scale and the importance of the information it collects, but there are difficulties and disagreements about how it is used. It is therefore a problem that the data collected are classified by clinicians on a scale in a subjective manner and the rating is different when it comes to using technical means. Thus, there is a great chance that when research is done by individuals of different specialties, greater emphasis is placed on the rating and evaluation of each individual specialty. Nevertheless, it is under investigation if this issue actually raises real problems in the patient's final assessment during his/her hospitalization and nothing is yet certain as new investigations are constantly underway and new questions are continually being answered. ${ }^{7}$

\section{SURVEY RESULTS}

A survey conducted in Canada by Rockwood and his associates was conducted in three stages. In the first stage, the frailty was clarified based on its phenotype, in the second stage the deficits were measured, but at the clinical level it was a cumbersome method and in the third and final stages the Clinical Frailty Scale was analyzed, studied and valida- 
ted. The results of the survey showed that people who seemed to be weaker were old and the majority were women. In addition, these individuals were observed to have problems related to their mental state, incontinence and motor problems, while most of them were also associated with other co-existing diseases. From the total of the measurements, conclusions were made that relate to post-hospitalization mortality or the need to introduce weak people into a care institution (Tables 3,4$){ }^{7}$
Another study, carried out in France in four different ICUs, was designed to show the correlation between the presence of frailty in the elders entering the ICU and that this diagnosis could predict the evolution of the patients' health status or the likelihood of their mortality. For this study, the frailty phenotype was used in conjunction with the Clinical Frailty Scale as well as the prognostic scales that are specific for the prognosis of patients in intensive care units such as Saps II and SOFA (Table 5). ${ }^{8}$

Table 3. Distribution of the frailty syndrome based on the Clinical Frailty Scale in Canada (CSHA)

\begin{tabular}{|c|c|c|c|c|c|c|c|}
\hline & $\begin{array}{l}1 \\
\text { Very good } \\
\text { physical } \\
\text { condition }\end{array}$ & $\begin{array}{l}2 \\
\text { Good } \\
\text { physical } \\
\text { condition }\end{array}$ & $\begin{array}{l}3 \\
\text { Properly } \\
\text { managed }\end{array}$ & $\begin{array}{l}4 \\
\text { Vulner- } \\
\text { able }\end{array}$ & $\begin{array}{l}5 \\
\text { Moderate- } \\
\text { ly weak }\end{array}$ & $\begin{array}{l}6 \\
\text { Severe } \\
\text { weak }\end{array}$ & $\begin{array}{l}7 \\
\text { Serious } \\
\text { weakness }\end{array}$ \\
\hline \multicolumn{8}{|l|}{ Characteristics } \\
\hline Patients & 216 & 260 & 476 & 349 & 305 & 497 & 194 \\
\hline Age(SD) & $80.3(5.9)$ & $83.0(63.8)$ & $82.4(6.3)$ & $83.7(6.2)$ & $86.4(6.5)$ & $87.4(6.7)$ & 88.1 \\
\hline Educational level (SD) & $9.6(4.1)$ & $9.9(4.2)$ & $9.6(4.1)$ & $8.8(3.7)$ & $9.7(4.1)$ & $9.4(3.9)$ & 9.1 \\
\hline Women \% & 51.8 & 58.5 & 57.1 & 56.2 & 64.6 & 68.6 & 80.4 \\
\hline No mental malfunction & 75.9 & 63.1 & 57.1 & 39.3 & 18.7 & 9.7 & 1.0 \\
\hline $\begin{array}{l}\text { With mental malfunction without } \\
\text { denial \% }\end{array}$ & 20.4 & 29.2 & 34.9 & 45.6 & 39.7 & 21.5 & 5.8 \\
\hline Denials \% & 3.7 & 7.7 & 8.0 & 15.2 & 41.6 & 68.8 & 93.3 \\
\hline Falls \% & 13.0 & 20.8 & 24.6 & 40.4 & 45.9 & 48.7 & 31.4 \\
\hline Incontinence & 8.3 & 12.3 & 17.2 & 26.6 & 31.8 & 60.4 & 92.8 \\
\hline Reduced mobility & 0.5 & 0.3 & 5.2 & 18.3 & 37.7 & 57.9 & 63.4 \\
\hline $\begin{array}{l}\text { Modified Mini-mental state examina- } \\
\text { tion, mean score }(\mathrm{SD})\end{array}$ & 87.1 & $82.6(13.9)$ & $83.2(12.7)$ & $79.1(13.3)$ & $70.2(17.7)$ & $56.2(22.2)$ & $31.9(21.0)$ \\
\hline Cumulative Disease Scale (SD) & $1.8(1.9)$ & $2.5(2.3)$ & $4.9(2.8)$ & $6.2(3.1)$ & $6.4(3.9)$ & $7.0(4.0)$ & $6.4(4.7)$ \\
\hline CSHA Measurement Tools (SD) & $0.72(1.01)$ & $1.14(1.09)$ & $1.34(1.08)$ & $1.90(0.95)$ & $2.45(0.71)$ & $2.82(0.4)$ & $2.94(0.23)$ \\
\hline Frailty index (SD) & $0.09(0.05)$ & $0.12(0.05)$ & $0.16(0.07)$ & $0.22(0.08)$ & $0.27(0.09)$ & $0.36(0.09)$ & $0.43(0.09)$ \\
\hline Functional scale (SD) & $0.05(0.12)$ & $0.11(0.16)$ & $0.15(0.19)$ & $0.27(0.22)$ & $0.45(0.24)$ & $0.71(0.24)$ & $0.87(0.19)$ \\
\hline
\end{tabular}

Table 4. Proportional risk up to the time of death and institutionalization

\begin{tabular}{lll}
\hline & Death HR (95\% CI) & $\begin{array}{l}\text { Introduction to an } \\
\text { institution }\end{array}$ \\
\hline Factors & & $1.15(1.10-1.13)$ \\
Age & $1.08(1.07-1.08)$ & $1.38(1.21-1.58)$ \\
Sex & $0.83(0.78-0.89)$ & $0.98(0.97-0.99)$ \\
Educational level & $0.98(0.97-0.99)$ & $0.65(0.60-0.70)$ \\
Modified Mini-mental state examination, mean score(SD) & $0.84(0.82-0.86)$ & $1.22(1.16-1.27)$ \\
Cumulative scale of disease & $1.14(1.11-1.17)$ & $1.27(1.19-1.35)$ \\
CSSH measurement tools & $1.17(1.13-1.20)$ & $1.56(1.48-1.65)$ \\
Frailty index & $1.26(1.24-1.29)$ & $1.29(1.20-1.39)$ \\
Functional scale & $1.16(1.13-1.20)$ & $1.46(1.39-1.53)$ \\
Clinical Frailty Scale & $1.30(1.27-1.33)$ & \\
\hline
\end{tabular}


Table 5. Key features, frailty, degrees of concomitant diseases, memory status

\begin{tabular}{|c|c|c|c|c|c|c|c|}
\hline & $\begin{array}{l}\text { Total } \\
(n=196)\end{array}$ & $\begin{array}{l}\text { Non-frail } \\
\text { FP <3 } \\
(n=116)\end{array}$ & $\begin{array}{l}\text { Frail } F P \geq 3 \\
(n=80)\end{array}$ & $\mathbf{p}$ & $\begin{array}{l}\text { Non- frail } \\
\text { CFS }<5 \\
(n=150)\end{array}$ & $\begin{array}{l}\text { Frail } \\
\text { CFS } \geq 5 \\
(n=46)\end{array}$ & $\mathbf{p}$ \\
\hline Age, years & $75 \pm 6$ & $74 \pm 6$ & $75 \pm 6$ & 0.96 & $75 \pm 6$ & $76 \pm 7$ & 0.34 \\
\hline Sex, male & $128(65)$ & $72(62)$ & $56(70)$ & 0.25 & $100(67)$ & $28(61)$ & 0.47 \\
\hline BMI, $\mathrm{kg}, \mathrm{m}^{-2}$ & $28 \pm 6$ & $28 \pm 5$ & $28 \pm 8$ & 0.45 & $28 \pm 5$ & $30 \pm 10$ & 0.12 \\
\hline \multicolumn{8}{|l|}{ Input time } \\
\hline Pathological causes & $50(26)$ & $31(27)$ & $19(24)$ & & $34(23)$ & $16(35)$ & \\
\hline Scheduled surgery & $52(26)$ & $24(21)$ & $28(35)$ & 0.09 & $42(28)$ & $10(22)$ & 0.25 \\
\hline Urgent surgery & $76(39)$ & $47(40)$ & $29(36)$ & & $58(39)$ & $18(39)$ & \\
\hline Trauma & $18(9)$ & $14(12)$ & $4(5)$ & & $16(11)$ & $2(4)$ & \\
\hline \multicolumn{8}{|l|}{ On input } \\
\hline Brain damage & $40(20)$ & $28(24)$ & $12(15)$ & 0.12 & $32(21)$ & $8(17)$ & 0.56 \\
\hline Heart attack & $15(8)$ & $8(7)$ & $7(9)$ & 0.60 & $8(5)$ & $7(15)$ & 0.05 \\
\hline Infection & $85(43)$ & $46(40)$ & $39(49)$ & 0.21 & $64(43)$ & $21(46)$ & 0.72 \\
\hline SAPS II & $48 \pm 17$ & $49 \pm 17$ & $47 \pm 16$ & 0.52 & $48 \pm 17$ & $49 \pm 16$ & 0.51 \\
\hline Modified SAPS II & $33 \pm 16$ & $32 \pm 16$ & $33 \pm 17$ & 0.52 & $32 \pm 17$ & $34 \pm 16$ & 0.57 \\
\hline SOFA & $7 \pm 4$ & $7 \pm 4$ & $7 \pm 3$ & 0.65 & $7 \pm 4$ & $7 \pm 3$ & 0.93 \\
\hline Glasgow scale & $11 \pm 5$ & $11 \pm 5$ & $11 \pm 5$ & 0.51 & $11 \pm 5$ & $11 \pm 5$ & 0.98 \\
\hline \multicolumn{8}{|l|}{ McCabe score } \\
\hline A & $88(45)$ & $64(55)$ & $24(30)$ & & $75(50)$ & $13(28)$ & \\
\hline B & $85(43)$ & $43(37)$ & $42(52)$ & 0.0014 & $61(41)$ & $24(52)$ & 0.02 \\
\hline $\mathrm{C}$ & $23(12)$ & $9(8)$ & $14(18)$ & & $14(9)$ & $9(20)$ & \\
\hline CFS & $3.7 \pm 1.6$ & $2.9 \pm 1.3$ & $4.8 \pm 1.3$ & $<0.0001$ & - & - & - \\
\hline FP & - & - & - & - & $1.7 \pm 1.4$ & $3.3 \pm 1.1$ & $<0.0001$ \\
\hline Charlson score & $2.1 \pm 2.0$ & $1.8 \pm 1.8$ & $2.5 \pm 2.1$ & 0.006 & $1.9 \pm 2.0$ & $2.6 \pm 1.9$ & 0.05 \\
\hline Katz score & $5.3 \pm 1.5$ & $5.8 \pm 0.8$ & $4.6 \pm 2.0$ & $<0.0001$ & $5.8 \pm 0.9$ & $3.7 \pm 2.1$ & $<0.0001$ \\
\hline Memory disorders & $43(22)$ & $18(16)$ & $25(31)$ & 0.01 & $27(18)$ & $16(35)$ & 0.02 \\
\hline
\end{tabular}

\section{CONCLUSIONS}

In recent years, many studies have been conducted on the onset of frailty syndrome in older patients. It has been observed that these individuals have features such as weight loss and muscle mass, a change in their eating habits in their movement and endurance, which make them more prone to adverse events. Perhaps these characteristics are the reason why there has been a marked increase in the use of ICU by the elderly. Thus, the association between the severely afflicted ICU-treated patients and the patients who are already diagnosed as weak or found at the onset of this syndrome is investigated. A patient with pre-existing frailty, and hence physical deficits, or a patient who is induced with a chronic or acute illness, is more likely to have an adverse outcome when he is hospitalized in an ICU. Additionally, these deficits accumulate more quickly and become more apparent during hospitalization and after a patient's discharge from the ICU. Therefore, if this correlation is concerned, there is great benefit for both the patients themselves and healthcare professionals using a tool capable of evaluating all of the above. Knowing the needs and deficits of each patient individually, it is possible to create a care plan suitable to cover all the patient's needs. In addition, a clearer picture of the patient's outcome is formed and this is equally beneficial in the use of resources in an ICU in which it is known how costly nursing is. Finally, it is positive that, beyond the prognosis of mortality in the ICU, a forecast of the quality of life that a patient will have at the end of his hospitalization and his/her exit from the unit can be achieved.

\section{Conflicts of Interest}

The authors have no conflicts of interest to declare. 


\section{Authors' contribution}

P.D. conceived and designed the study. All authors: administrative support, provision of study materials or patients, collection and assembly of data, data analysis and interpretation, manuscript writing, and final approval of manuscript.

\section{Ethical Statement}

The Ethical Review Board of our hospital approved this study (IRB\# 2016-04).

\section{REFERENCES}

1. McDermid RC, Stelfox HT, Bagshaw HT. Frailty in the critically ill: a novel concept. Critical Care 2011; 15(1):301.

2. Soyanal P, Stubbs B, Lucato P, et al. Corrigendum to "Inflammation and frailty in the elderly: A systematic review and meta-analysis"
[Ageing Res Rev. 31 (2016) 1-8]. Ageing Res Rev. 2017; 35:364-5.

3. Rockwood $\mathrm{K}$, Theou O, Mitnitski A. What are frailty instruments for? Age and Ageing 2015; 44(4):545-7.

4. Wold GH. Basic Geriatric Nursing. Athens: Parisianos GB: 2008.

5. Petty DR, House A, Knapp P, et al. Role of the funding source. School of Healthcare. 2006; 526-8.

6. Moorhouse P, Rockwood K. Frailty and its quantitative clinical evaluation. JR Coll Physicians Edinb. 2012; 42(4):333-40.

7. Rockwood $\mathrm{K}$, Song $\mathrm{X}$, MacKnight $\mathrm{C}$, et al. A global clinical measure of fitness and frailty in elderly people. CMAJ 2005; 173(5):498-95.

8. Le Maguet P, Roquilly A, Lasocki S, et al. Prevalence and impact of frailty on mortality in elderly ICU patients: a prospective, multicenter, observational stud. Intensive Care Med 2014; 40(5):674-82.

9. Vermeulen J, Neysen JCL, Van Rossum E, et al. Predicting ADL disability in community-dwelling elderly people using physical frailty indicators: a systematic review. BMC Geriatrics 2011;11:33.

10. Mac GJ, Hubbard RE. Frailty in older inpatients: what physicians need to know. QJM 2012;105(11):1059-65

11. Chalkidi E, Bellali T, Kyromiti A, et al. Exploring the psychosocial needs and satisfaction of the family of patients hospitalized in the Intensive Care Unit. Hellenic Journal of Nursing 2016; 9(3):44-55. 


\title{
Количественная оценка синдрома старческой астении у пациентов в отделении интенсивной терапии по клинической шкале старческой астении
}

\author{
Димитриос Папагеоргиу ${ }^{1}$, Константина Косенаи ${ }^{2}$, Елени Гика ${ }^{2}$, Димитриос Алефракис ${ }^{3,4}$, \\ Деспина Кеску ${ }^{4}$, Кристина Мандила \\ ${ }^{1}$ Отделение последующего наблюдения при отделении интенсивной терапии, Факультет сестринского дела, Университет Западной \\ Аттики, Абины, Греция \\ ${ }^{2}$ Сертифицированная медсестра, Афины, Греция \\ ${ }^{3}$ Больница „Эррикос Дюнан“, Афинь, Греция \\ ${ }^{4}$ Медицинский факультет, Афинский национальньй университет имени Каподистрии, Афинь, Греция \\ ${ }^{5}$ Отделение интенсивной терапии, Афинская больница „Геогиос Генниматас“, Афинь, Греиия
}

Адрес для корреспонденции: Димитриос Папагеоргиу, Отделение последующего наблюдения при отделении интенсивной терапии, Факультет сестринского дела, Университет Западной Аттики, Афины, Греция; E-mail: dpapa@teiath.gr

Дата получения: 24 января 2020 • Дата приемки: 15 апреля 2020 Дата публикации: 31 декабря 2020

Образец цитирования: Papageorgiou D, Kosenai K, Gika E, Alefragkis D, Keskou D, Mandila C. Quantification of frailty syndrome in ICU patients with clinical frailty scale. Folia Med (Plovdiv) 2020;62(4):655-61. doi: 10.3897/folmed.62.e50433.

\section{Резюме}

Количественная оценка старческой астении полезна как для понимания природы синдрома, так и для разработки плана интенсивной терапии для пациентов, страдающих от него. Зная потребности и недостатки каждого пациента индивидуально, можно составить план, который подходит для удовлетворения всех потребностей пациентов. Инструменты, используемые сегодня для количественной оценки синдрома старческой астении, включают фенотип Фрида, индекс старческой астении, шкалу оценки симптомов Эдмонтона и клиническую шкалу старческой астении. Клиническая шкала старческой астении - одна из самых простых в использовании шкал с особой прогностической ценностью. Путём регистрации и анализа собранной информации и ранжирования больных в отделении интенсивной терапии по девяти баллам шкалы можно прийти к правильным прогнозным выводам о смертности или необходимости помещения в лечебное учреждение, которые будут иметь место в ближайшие пять лет.

\section{Ключевые слова}

тяжелобольные пациенты, синдром старческой астении, отделение интенсивной терапии 